9 Revista Latinoamericana de la Papa 20 (1): 9-17

ISSN: $1853-4961$ http://www.papaslatinas.org/ojs/index.php/index/oai

\title{
Breeding for nutritional quality and pest resistance: potential of a set of non-commercial tetraploid potato cultivars with purple and red flesh
}

\author{
R. Tierno ${ }^{1}$ and J. I. Ruiz de Galarreta ${ }^{1 / *}$
}

Received: $27 / 08 / 2015$

Accepted: 13/01/2016

Accessible on line: June 2016

\begin{abstract}
Summary
Potatoes are the most widely cultivated tubers and also a valuable source of nutrients and nonnutrient health-promoting compounds. Cultivars with pigmented skin and flesh are of especial interest due to the presence of high concentrations of carotenoids, anthocyanins, flavonoids and phenolic acids. Several investigations have focused on the characterization of native and wild potato accessions, particularly highly pigmented genotypes in order to broaden the overall genetic variation in terms of commercial and processing aptitude, pest resistance and nutritional quality. However, the incorporation of some of these traits into new breeding lines at the tetraploid level is hampered by the presence of detrimental traits as well as varying ploidy levels. Therefore, a set of ten highly-pigmented tetraploid cultivars (Solanum tuberosum L.) was selected and characterized on the basis of tuber morphology, pest resistance and nutritional related traits in order to select parental lines for breeding. Attractive colors and color patterns with potential for the potato snack industry have been identified. Varying degrees of resistance to Globodera spp. and Phythophora infestans, which are considered major threats for the crop, have been found among the collection of pigmented cultivars. Nutritional quality related parameters including significantly higher levels of phenolic compounds, anthocyanins, carotenoids, vitamin $\mathrm{C}$ and micronutrients ( $\mathrm{Zn}$ and $\mathrm{Fe}$ ) were found when compared with the commercial cultivars used as checks. These findings could assist in the selection of parents (progenitors) towards the introduction of interesting traits into new potato advanced clones at the tetraploid level, without the problems derived from ploidy levels and non-commercial characteristics.
\end{abstract}

Additional Key words: characterization, minerals, vitamin C, bioactive compounds, progenitors.

\section{Mejora para calidad nutricional y resistencia a enfermedades: potencial de un grupo de cultivares de patata tetraploides no comerciales de carne roja o morada}

\section{Resumen}

La papa es uno de los tubérculos más extensamente cultivado y constituye una fuente valiosa de nutrientes y compuestos bioactivos. Los cultivares con la piel y la carne pigmentadas son particularmente interesantes debido a la presencia de altas concentraciones de carotenoides, antocianinas, flavonoides y ácidos fenólicos. Se han realizado numerosas investigaciones enfocadas a la caracterización de introducciones nativas y silvestres de papas, especialmente centradas en el estudio de genotipos pigmentados, y con el objetivo de ensanchar la base genética en términos de aptitud comercial y de procesado, resistencia a plagas y calidad nutricional. Sin embargo, la incorporación de algunos de estos caracteres en nuevas líneas de

\footnotetext{
* Contact author. E-mail: jiruiz@neiker.eus

${ }^{1}$ Neiker Tecnalia, Campus Agroalimentario de Arkaute - E-01080 Vitoria-Gasteiz (Araba), España.
} 
mejora a nivel tetraploide se ve dificultada por la presencia de características perjudiciales así como niveles variables de ploidía. Para la realización de este trabajo, una colección de diez cultivares de patata tetraploide (Solanum tuberosum L.) fue seleccionada y caracterizada en base a la morfología del tubérculo, la resistencia a plagas y parámetros relacionados con la calidad nutricional, con el objetivo de seleccionar parentales de mejora. Se identificaron colores atractivos y distribuciones de colores con potencial para la industria de producción de chips. Se han hallado diferentes niveles de resistencia a Globodera spp. y Phythophora infestans, las cuales se incluyen entre los principales patógenos del cultivo. Los parámetros relacionados con la calidad nutricional incluyeron niveles considerablemente más altos de compuestos fenólicos, antocianinas, carotenoides, vitamina $\mathrm{C}$ y algunos micronutrientes ( $\mathrm{Zn}$ y Fe) comparados con los obtenidos en los cultivares comerciales usados como controles. Estos resultados pueden contribuir en la selección de progenitores para la introducción de rasgos interesantes en nuevos clones avanzados de papa a nivel tetraploide sin los inconvenientes derivados de la existencia de características no comerciales y niveles de ploidía variables.

Palabras clave adicionales: Caracterización, minerales, vitamina $\mathrm{C}$, componentes bioactivos, progenitores.

\section{Introduction}

Potatoes are a valuable source of carbohydrates, proteins, minerals and vitamins (Fernie and Willmitzer, 2001). Highly-pigmented potato cultivars have also been reported to show high levels of health promoting phytochemicals, even higher than those of certain berries and fruits (Tierno et al., 2015). Moreover, worldwide annual potato consumption per capita reaches to more than $30 \mathrm{~kg}$, exceeding $80 \mathrm{~kg}$ in several countries of America and Northern and Eastern Europe (Helgi-Library, 2015). Thus, potatoes and particularly deep colored genotypes could be considered as a very important source of minerals, vitamins and bioactive compounds for the human diet.

For this reason, during the last decades several researches have focused both on the characterization of native and wild potato genotypes as a source of nutritional quality related traits and on the design of suitable breeding strategies (Spooner et al., 2005; Burgos et al., 2007; Lindhout et al. 2011). However, the utilization of native and wild germplasm in potato breeding programs at the tetraploid level is hampered by the presence of noncommercial characteristics, ploidy levels and lack of adaptation to temperate zones (Ruiz de Galarreta et al. 2015).

In this context, a collection of ten highlypigmented tetraploid Solanum tuberosum L. cultivars was selected and characterized in terms of tuber morphology, pathogens resistance and nutritional related traits with the aim of selecting parental lines at the tetraploid level without problems derived from the utilization of non-adapted native or wild potato cultivars with different ploidy levels and detrimental characteristics.fertilization with Fe y $\mathrm{Zn}$, in order to make it possible for this nutrients to be absorbed in higher proportion by the tubers and so for to be available in the needed quantities for human nutrition, particularly in areas where there is deficiency of this micronutrients (Devaux, 2013).

Previous studies, in agronomic biofortification, were performed by Val Verde et al. (2013) in Ecuador. They applied $\mathrm{Fe}$ and $\mathrm{Zn}$ to the soil and to the foliage in five cultivar of potatoes (some native others bred), their results showed that the concentrations of $\mathrm{Fe}$ and $\mathrm{Zn}$ in the tubers were high, though not of significance. Besides, in Perú, Burgos et al. (2007) characterised 37 native cultivars of potato for its content of $\mathrm{Fe} y \mathrm{Zn}$ and 
found out that some of the cultivars reached the deliverance of 29 y $26 \%$ of the recommended ingest $\left(6 \mathrm{mg}^{-d a y^{-1}}\right.$ and $\left.4.1 \mathrm{mg}^{-\mathrm{day}^{-1}}\right)_{\text {) }} \mathrm{Fe} \mathrm{y} \mathrm{Zn}$ respectively. These results, for children 1 to 3 years old, with an average consumption of potato of 200 g.day ${ }^{-1}$.

This present research had two objectives: a) determinations of the differentiated response of two native potato cultivars to different levels of fertilization of $\mathrm{Fe}$ and $\mathrm{Zn}$ in soil in three different towns in Bolivia and b) determine the content of $\mathrm{Fe}$ and $\mathrm{Zn}$ in the tubers for each level of fertilization applied in each of the two native potato cultivars.

\section{Materials and Methods}

Ten highly-pigmented cultivars were selected from potato accessions of the Potato Germplasm Collection, NEIKER (Table 1) and grown during the year 2013 in a precise field trial in Arkaute (Alava) in the north of Spain (500 masl) with a humid climate and annual rainfall of about $800 \mathrm{~L}$ $\mathrm{m}^{-2}$. The soil with a clay loam texture was previously subjected to conventional wheat cropping. Plants were grown from midMay to mid-October 2013 aftre pre-sowing fertilization with $800 \mathrm{~kg} \mathrm{ha}^{-1}$ (N-P-K 4-816). Watering was performed using an automatic spray irrigation system. After harvesting potatoes were stored at $4^{\circ} \mathrm{C}$ in a darkened cold room for 1 month.

Table 1. Collection of ten highly-pigmented Solanum tuberosum L. cultivars.

\begin{tabular}{ll}
\hline Cultivar & Origin \\
\hline Bleu de La Manche & France \\
Blue Congo & Sweden \\
British Columbia Blue & Canada \\
CIP-7002/34 & Peru \\
Highland Burgundy & \\
Red & France \\
Morada & Spain \\
Purple Peruvian & Peru \\
Rouge de Flandes & Belgium \\
Valfi & Sweden \\
Vitelotte & France \\
\hline
\end{tabular}

Morphological characterization of tubers was performed considering six descriptors from UPOV (1984). The evaluation of resistance of the set of colored potato cultivars to Globodera pallida (Stone) and G. rostochiensis (Woll.) was performed in triplicate with greenhouse bioassays following the methodology described by Ruiz de Galarreta et al. 1998 and Alor et al. 2015. Cultivars were classified according to Rousselle-Burgeois and Mugniery (1998) (< 5 cysts were classified as resistant, 5-20 cysts as partially resistant and $>20$ cysts as susceptible cultivars).
Resistance to Phythophora infestans (Mont.) de Bary was evaluated according to Vleeshouwers et al. (1999) by estimating the area under disease progress curve (AUDPC), as described by (Bonierbale et al. (2008). A total of eight tubers of each cultivar were selected, peeled and freeze-dried. Analyses were performed in triplicate. Sample preparation and chemical analysis of total soluble phenolics (TSP), total monomeric anthocyanins (TMA), total carotenoids (TC), vitamin $\mathrm{C}$ (VC) and minerals ( $\mathrm{Zn}$ and $\mathrm{Fe}$ ) for nutritional characterization of 
tubers were performed according to Tierno et al. (2015). The commercial cultivars Panda and Monalisa were selected as controls for nutritional quality related parameters because they are commonly

\section{Results and Discussion}

Morphological characterization of tubers showed different colors and color-patterns among the collection of colored potatoes, including interesting combinations consisting in purple or red potato hearts surrounded by light or yellow fleshed halos, mosaic patterned cultivars and also totally anthocyanin-colored tubers (Table cultivated potato varieties with different commercial characteristics and varying processing quality parameters. Statistical analyses were performed using $\mathrm{R}$ ( $\mathrm{R}$ Development Core Team, 2008). 2). The incorporation of these interesting traits into new potato advanced clones could satisfy the increasing demand of special and exotic food products, such as colored chips and snacks, with advantages in terms of organoleptic and nutritional quality (Ruiz de Galarreta et al. 2015). Most cultivars produced oval or long shaped tubers with medium or deep anthocyanin base-colored eyes.

Table 2. Morphological characterization of the collection of tubers.

\begin{tabular}{lllll}
\hline Cultivars & $\begin{array}{l}\text { Skin/Flesh } \\
\text { type }^{1}\end{array}$ & Tuber shape $^{2}$ & Eye depth $^{\mathbf{3}}$ & $\begin{array}{l}\text { Color of base } \\
\text { of eye }^{\mathbf{4}}\end{array}$ \\
\hline Bleu de La Manche & $\mathrm{P} / \mathrm{PW}$ & $\mathrm{SOV}$ & $\mathrm{M}-\mathrm{D}$ & $\mathrm{B}$ \\
Blue Congo & $\mathrm{P} / \mathrm{PW}$ & $\mathrm{OV}-\mathrm{L}$ & $\mathrm{M}-\mathrm{D}$ & $\mathrm{B}$ \\
British Columbia Blue & $\mathrm{P} / \mathrm{PW}$ & $\mathrm{OV}$ & $\mathrm{M}-\mathrm{D}$ & $\mathrm{B}$ \\
CIP-7002/34 & $\mathrm{R} / \mathrm{RY}$ & $\mathrm{R}$ & $\mathrm{D}$ & $\mathrm{R}$ \\
Highland Burgundy & & & & \\
Red & $\mathrm{P} / \mathrm{RY}$ & $\mathrm{L}$ & $\mathrm{S}$ & $\mathrm{R}$ \\
Morada & $\mathrm{P} / \mathrm{YP}$ & $\mathrm{OV}$ & $\mathrm{S}$ & $\mathrm{B}$ \\
Purple Peruvian & $\mathrm{P} / \mathrm{P}$ & $\mathrm{VL}$ & $\mathrm{D}$ & $\mathrm{B}$ \\
Rouge de Flandes & $\mathrm{P} / \mathrm{RY}$ & $\mathrm{L}$ & $\mathrm{S}$ & $\mathrm{R}$ \\
Valfi & $\mathrm{P} / \mathrm{WP}$ & $\mathrm{OV}$ & $\mathrm{M}-\mathrm{D}$ & $\mathrm{B}$ \\
Vitelotte & $\mathrm{P} / \mathrm{P}$ & $\mathrm{VL}$ & $\mathrm{D}$ & $\mathrm{B}$ \\
\hline
\end{tabular}

${ }$ Key to skin and tuber flesh types: $\mathrm{R}=$ Red, $\mathrm{P}=$ Purple, $\mathrm{Y}=$ Yellow and $\mathrm{W}=$ White. ${ }^{2}$ Key to tuber shape: $\mathrm{R}=$ Round, $\mathrm{SOV}=$ Short Oval, OV $=$ Oval, $\mathrm{L}=$ Large and VL $=$ Very large. ${ }^{3}$ Key to eye depth: $\mathrm{VS}=$ Very shallow, $\mathrm{S}=$ Shallow, $\mathrm{M}=$ Medium and $\mathrm{D}=$ Deep. ${ }^{4}$ Key to color of base of eye: $\mathrm{L}=$ Long and $\mathrm{VL}=$ Very long.

The evaluation of resistance against Globodera spp. and Phythophora infestans, which are considered major threats affecting potato production worldwide (Rich, 2013), revealed interesting results (Table 3). A total of four accessions (cvs. Blue Congo, Morada, Rouge de Flandes and Vitelotte) were identified as partially resistant to G. pallida
(Pa 2/3). Three of them also showed total (cv. Blue Congo) or partial resistance (cvs. Morada and Vitelotte) to G. rostochiensis (Ro 1/4). On the other hand, the cultivar Valfi was classified as moderately resistant to $P$. infestans (13_A2_68). The levels of resistance found among the set of colored cultivars could be utilized to introduce pest resistance related traits in the context of a potato breeding program. 
Table 3. Resistances found among the collection of cultivars.

\begin{tabular}{llll}
\hline Cultivars & $\begin{array}{l}\text { Globodera } \\
\text { pallida }^{\text {1 }}\end{array}$ & $\begin{array}{l}\text { Globodera } \\
\text { rostochiensis }\end{array}$ & $\begin{array}{c}\text { Phytophthora } \\
\text { infestans }^{3}\end{array}$ \\
\hline Bleu de La Manche & $\mathrm{S}$ & $\mathrm{S}$ & $\mathrm{S}$ \\
Blue Congo & $\mathrm{PR}$ & $\mathrm{R}$ & $\mathrm{S}$ \\
British Columbia Blue & $\mathrm{S}$ & $\mathrm{S}$ & $\mathrm{S}$ \\
CIP-7002/34 & $\mathrm{S}$ & $\mathrm{S}$ & $\mathrm{S}$ \\
Highland Burgundy & & $\mathrm{S}$ & $\mathrm{S}$ \\
Red & $\mathrm{S}$ & $\mathrm{PR}$ & $\mathrm{S}$ \\
Morada & $\mathrm{PR}$ & $\mathrm{S}$ & $\mathrm{S}$ \\
Purple Peruvian & $\mathrm{S}$ & $\mathrm{S}$ & $\mathrm{S}$ \\
Rouge de Flandes & $\mathrm{PR}$ & $\mathrm{S}$ & $\mathrm{PR}$ \\
Valfi & $\mathrm{S}$ & $\mathrm{PR}$ & $\mathrm{S}$ \\
Vitelotte & $\mathrm{PR}$ &
\end{tabular}

Pathotype: Pa $2 / 3 ;{ }^{2}$ Pathotype: Ro $1 / 4 ;{ }^{3}$ Isolate: $13 \_$A2_68

$\mathrm{S}=$ Susceptible; $\mathrm{PR}=$ Partially Resistant and $\mathrm{R}=$ Resistant

Statistical analysis revealed significance differences between cultivars for all the studied nutritional parameters $(P \leq 0.05)$ (Table 4). Total soluble phenolics (TSP) concentrations, ranging from $0.189 \pm 0.035$ (cv. Monalisa) to $2.149 \pm 0.048 \mathrm{~g} \mathrm{GAE} \mathrm{kg}^{-1}$ fw (cv. Highland Burgundy Red), were higher in purple and red fleshed cultivars (Figure 1A). The highest TSP levels (cvs. Highland Burgundy Red and Purple Peruvian) were more than five times higher than those of the commercial cultivars used as testers. Higher levels of phenolic acids and other bioactive compounds have been previously reported in purple and red fleshed cultivars (Brown, 2005). Total monomeric anthocyanins (TMA) levels found in this study ranged from 0 to $1.311 \pm 0.096 \mathrm{~g} \mathrm{CGE} \mathrm{kg}^{-1}$ fw (Figure 1B). As shown in Figure $1 \mathrm{C}$, total carotenoid levels (TC) were higher in partially yellow fleshed accessions (cv. CIP-7002/34 and Morada) and ranged from $0.009 \pm 0.002(\mathrm{cv}$. Bleu de La Manche) to $0.097 \pm 0.018 \mathrm{~g} \mathrm{LE}$ $\mathrm{kg}^{-1} \mathrm{fw}$ (cv. CIP-7002/34). On the other hand, concentration of vitamin $\mathrm{C}$ (VC) ranged from $0.040 \pm 0.007$ (cv. CIP$7002 / 34$ ) to $0.107 \pm 0.020 \mathrm{~g} \mathrm{~kg}^{-1} \mathrm{fw}$ (cv. Blue Congo) (Figure 1D). When comparing with Panda and Monalisa, accessions with significantly higher levels of TC (cvs. CIP-7002/34 and Morada) and VC (cvs. Blue Congo, Morada and Purple Peruvian) have been identified within the collection. Despite the fact that potato is considered a valuable source of vitamin $C$, data extracted from the present study revealed significantly low concentrations of this vitamin among the collection of pigmented cultivars. In this sense, several studies have shown that vitamin $\mathrm{C}$ levels are highly dependent on many environmental factors (Dale et al. 2003). 
Table 4. Comparison of means of the characters: total carotenoids expressed as $\mathrm{g}$ lutein equivalents per $\mathrm{kg}$ fresh weight (TC), vitamin $\mathrm{C}$ (VC) expressed as g vitamin $\mathrm{C}$ per $\mathrm{kg}$ fresh weight, total soluble phenolics (TSP) expressed as g gallic acid equivalents per $\mathrm{kg}$ fresh weight, total monomeric anthocyanins expressed as g cyaninin-3-O glucoside equivalents per $\mathrm{kg}$ fresh weight (TMA), zinc expressed as $\mathrm{g}$ of $\mathrm{Zn}$ per $\mathrm{kg}$ fresh weight ( $\mathrm{Zn}$ ) and iron expressed as $\mathrm{g} F$ per $\mathrm{kg}$ fresh weight $(\mathrm{Fe})$ evaluated in ten potato cultivars.

\begin{tabular}{|c|c|c|c|c|c|c|c|c|c|c|c|c|}
\hline Cultivar & TSP & & TMA & & TC & & VC & & $\mathbf{Z n}$ & & $\mathbf{F e}$ & \\
\hline Highland Burgundy Red & 2.15 & $\mathrm{a}$ & 1.311 & $\mathrm{~A}$ & 0.036 & $\mathrm{c}$ & 0.058 & def & 0.021 & $a b c$ & 0.038 & $\mathrm{c}$ \\
\hline Purple Peruvian & 2.14 & $\mathrm{a}$ & 0.601 & $\mathrm{C}$ & 0.019 & de & 0.093 & $a b$ & 0.020 & bcd & 0.032 & $\mathrm{f}$ \\
\hline Vitelotte & 1.68 & $\mathrm{~b}$ & 0.455 & $\mathrm{D}$ & 0.035 & $\mathrm{c}$ & 0.067 & $\mathrm{~cd}$ & 0.020 & bcd & 0.051 & $\mathrm{a}$ \\
\hline Blue Congo & 1.18 & $\mathrm{c}$ & 0.298 & $\mathrm{E}$ & 0.010 & $\mathrm{e}$ & 0.107 & $\mathrm{a}$ & 0.022 & $\mathrm{abc}$ & 0.023 & $\mathrm{~h}$ \\
\hline British Columbia Blue & 1.13 & $\mathrm{c}$ & 0.331 & $\mathrm{E}$ & 0.016 & de & 0.058 & def & 0.023 & A & 0.030 & $\mathrm{~g}$ \\
\hline Rouge de Flandes & 1.09 & $\mathrm{c}$ & 1.011 & $\mathrm{~B}$ & 0.035 & $\mathrm{c}$ & 0.068 & $\mathrm{~cd}$ & 0.017 & $\mathrm{~F}$ & 0.034 & de \\
\hline Bleu de La Manche & 0.92 & $\mathrm{~d}$ & 0.334 & $\mathrm{E}$ & 0.009 & $\mathrm{e}$ & 0.083 & $\mathrm{bc}$ & 0.018 & $\mathrm{Ef}$ & 0.033 & ef \\
\hline CIP-7002/34 & 0.66 & $\mathrm{e}$ & 0.068 & $\mathrm{G}$ & 0.097 & $\mathrm{a}$ & 0.04 & $\mathrm{f}$ & 0.020 & cde & 0.043 & $\mathrm{~b}$ \\
\hline Valfi & 0.52 & $\mathrm{f}$ & 0.274 & $\mathrm{E}$ & 0.020 & d & 0.059 & de & 0.022 & $\mathrm{Ab}$ & 0.039 & $\mathrm{c}$ \\
\hline Morada & 0.51 & $\mathrm{f}$ & 0.193 & $\mathrm{~F}$ & 0.059 & $\mathrm{~b}$ & 0.106 & $\mathrm{a}$ & 0.020 & cde & 0.035 & $\mathrm{~d}$ \\
\hline Panda & 0.21 & $\mathrm{~g}$ & 0 & $\mathrm{G}$ & 0.021 & d & 0.047 & ef & 0.015 & $\mathrm{G}$ & 0.020 & $\mathrm{i}$ \\
\hline Monalisa & 0.19 & $\mathrm{~g}$ & 0 & $\mathrm{G}$ & 0.035 & $\mathrm{c}$ & 0.056 & def & 0.018 & def & 0.019 & $\mathrm{i}$ \\
\hline$L S D(0.05)$ & 0.11 & & 0.071 & & 0.010 & & 0.020 & & 0.002 & & 0.002 & \\
\hline
\end{tabular}

Means followed by different letters are significantly different at $P \leq 0.05$. 

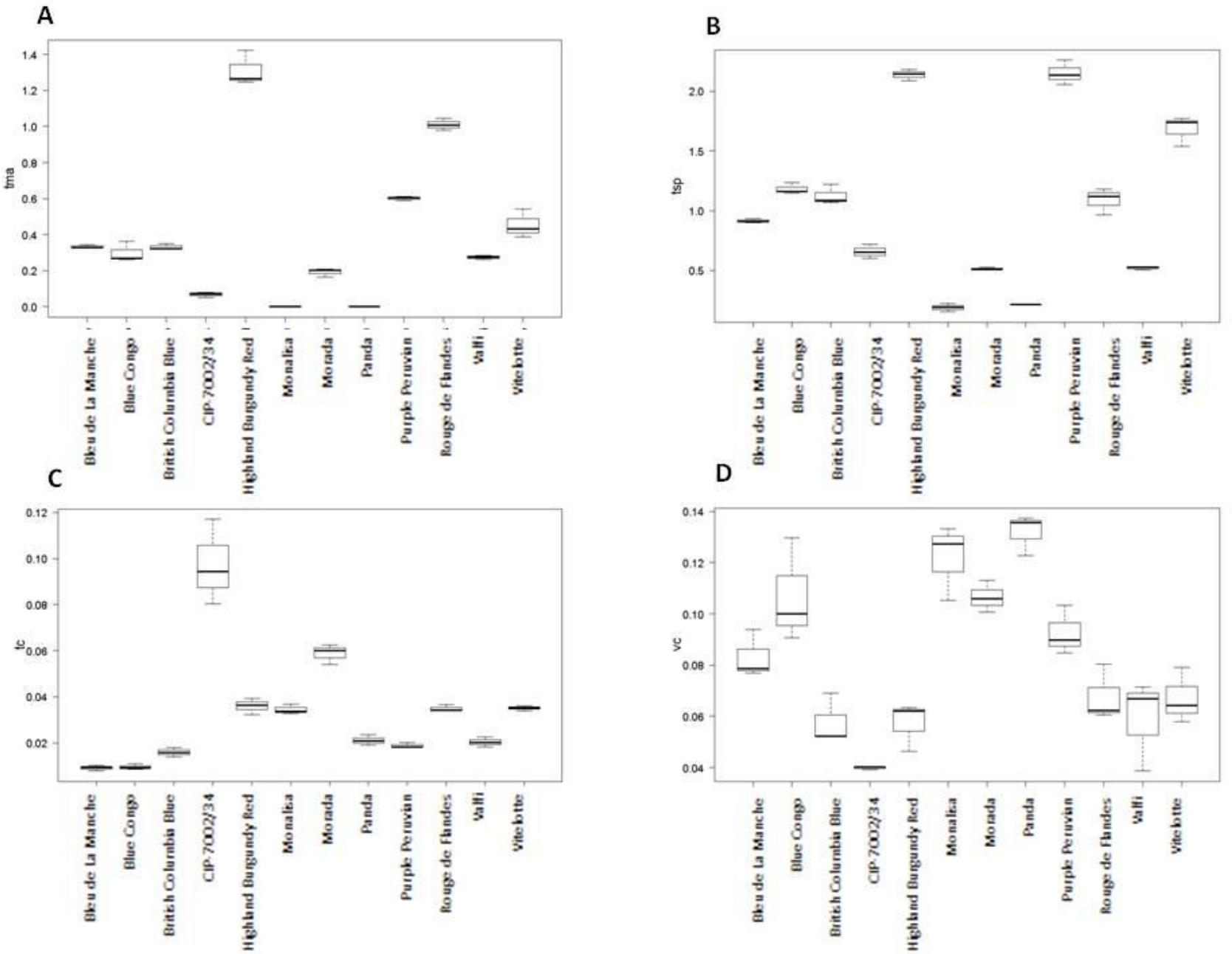

Figure 1. Boxplots indicating the distribution of the following phytochemical composition related parameters: A) total soluble phenolics (TSP), B) total monomeric anthocyanins (TMA), C) total carotenoids (TC) and D) vitamin C (VC) in peeled tubers of the collection of ten highly-pigmented cultivars. Means and standard deviations of: TSP are expressed as $\mathrm{g}$ gallic acid equivalents per kg fresh weight; TMA are expressed as g cyanidin 3-O-glucoside equivalents per $\mathrm{kg}$ fresh weight, $\mathrm{TC}$ are expressed as $\mathrm{g}$ lutein equivalents per $\mathrm{kg}$ fresh weight and VC are expressed as g vitamin $\mathrm{C}$ per $\mathrm{kg}$ fresh weight $(\mathrm{n}=3)$.

Micronutrient concentrations ranged from $0.015 \pm 0.001$ to $0.023 \pm 0.003$ for $\mathrm{Zn}$ $0.021 \pm 0.005$ to $0.051 \pm 0.002$ for Fe (Figure $2 \mathrm{~A}$ and 2B). Moreover, most highly pigmented cultivars showed significantly higher $\mathrm{Zn}$ (cvs. Blue Congo, British Columbia Blue, Valfi and Highland Burgundy Red) and Fe (Vitelotte, CIP7002/34, Highland Burgundy Red, Morada and Rouge de Flandes) concentrations. An average edible portion of Vitelotte contains more than $20 \%$ of the recommended daily intake of $\mathrm{Fe}$ and also about $10 \%$ of the dietary reference intake of $\mathrm{Zn}$ (Institute of Medicine: Food and Nutrition Board, 2001). Results obtained in this study, regarding tuber morphology, pest resistance and nutritional quality of a small set of highly-pigmented Solanum tuberosum L. cultivars revealed the existence, among them, of interesting traits: such as resistances to Globodera 
spp. and Phytophthora infestans; as well as significantly higher concentrations of phenolic compounds, carotenoids, vitamin $\mathrm{C}$, zinc and iron. These findings could be useful to assist in parental line selection for breeding with the aim of obtaining healthpromoting advanced clones with lower incidence of pests and diseases.
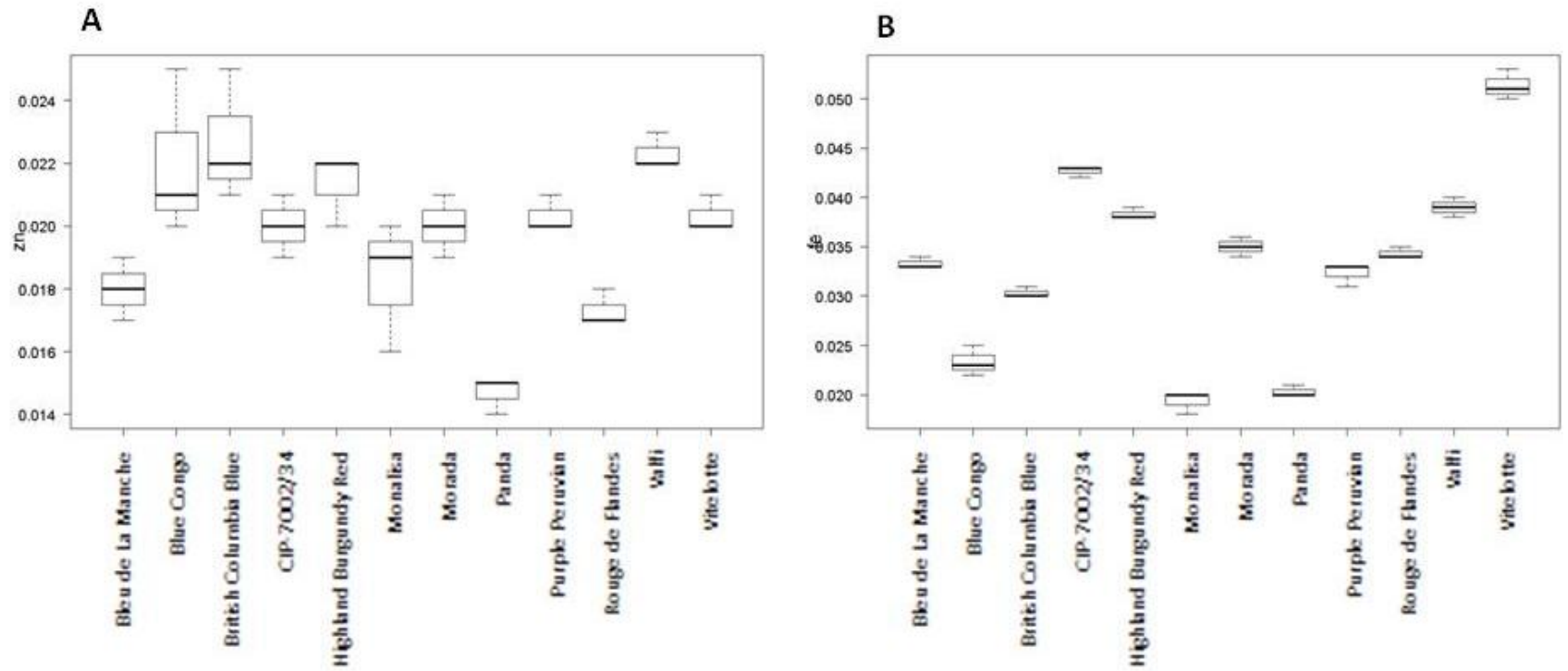

Figure 2. Boxplots indicating the distribution of the following mineral composition related parameters: A) zinc content $(\mathrm{Zn})$ and $\mathrm{B})$ iron content $(\mathrm{Fe})$. Means and standard deviations of $\mathrm{Zn}$ and $\mathrm{Fe}$ are expressed as $\mathrm{g}$ per $\mathrm{kg}$ fresh weight $(\mathrm{n}=3)$.

\section{Conflict of interests}

The authors declare there is no conflict of interest in the publication of the results of this research.

\section{Acknowledgements}

This work was financed within the frame of INIA's project RTA2013-00006-C03 and the Basque Government.

\section{References}

Alor, N.; R. López-Pardo; L. Barandalla; D. Ríos; E. Ritter; J.I. Ruiz de Galarreta. 2015. New sources of resistance to potato pathogens in old varieties of the Canary Islands. Pot. Res., 50: 135-146.

Bonierbale, M.; S. De Haan; A. Forbes. 2008. Procedures for standard evaluation trials of advanced potato clones. En: An international cooperators guide. International Potato Center, Lima, Peru. $124 \mathrm{pp}$.

Brown, C.R. 2005. Antioxidants in potato. Am. J. Pot. Res., 82: 163-172.

Burgos, G.; W. Amorós; M. Morote; J. Stangoulis; M. Bonierbale. 2007. Iron and Zinc Concentration of Native Andean Potato Cultivars from a Human Nutrition Perspective. J. Sci. Food Agric., 87: 668675.

Dale, M.F.B.; D.W. Griffiths; D.T. Todd. 2003. Effects of genotype, environment, and postharvest storage on the total ascorbate content of potato (Solanum tuberosum L.) tubers. J. Agric. Food Chem. 51: 244-248.

Helgi-Library. 2015. Potato Consumption Per Capita [Online]. Available on: 
http://www.helgilibrary.com [Consulted August 2015].

Institute of Medicine: Food and Nutrition Board. 2001. Dietary Reference Intakes for Vitamin A, Vitamin K, Arsenic, Boron, Chromium, Copper, Iodine, Iron, Manganese, Molybdenum, Nickel, Silicon, Vanadium, and Zinc : a Report of the Panel on Micronutrients. Washington, DC: National Academy Press, 2001.

Lindhout, P.; D. Meijer; T. Schotte; R.C.B. Hutten; R.G.F. Visser; H.J. van Eck. 2011. Towards $\mathrm{F}_{1}$ Hybrid Seed Potato Breeding. Pot. Res., 54: 301-312.

R Development Core Team. 2008. R: A language and environment for statistical computing. R Foundation for Statistical Computing,Vienna, Austria. ISBN 3900051-07-0, URL http://www.Rproject.org.

Rich, A.E. 1983. Potato Diseases. New York: Academic Press Inc., 1983.

Rousselle-Bourgeois, F.; D. Mugniéry. 1995. Screening tuber-bearing Solanum spp. For resistance to Globodera rostochiensis Ro1 Woll. and G. pallid $\mathrm{Pa}$ 2/3 Stone. Potato Res 38: 241-249.

Ruiz de Galarreta, J.I.; A. Carrasco; A. Salazar; I. Barrena; E. Iturritxa; R. Marquínez; J. Legorburu; E. Ritter. 1998. Wild Solanum species as resistance sources against different pathogens of potato. Pot. Res., 41: 57-68.
Ruiz de Galarreta, J.I.; R. López; R. Tierno; N.A. Alor-Romero; L. Barandalla; N. Haase. 2015. Disease resistance and nutritional properties of tuber-bearing native potato species and old Spanish cultivars. J. Agric. Sci. Tech., 17: 935-947.

Spooner, D.M.; K. McKlean; G. Ramsay; R. Waugh; G.J. Bryan. 2005. A Single Domestication for Potato Based on Multilocus AFLP Genotyping. Proc. Natl. Acad. Sci. USA, 102: 14694-14699.

Tierno, R.; A. López; P. Riga; S. Arazuri; C. Jarén; L. Benedicto; J. I. Ruiz de Galarreta. 2015. Phytochemicals determination and classification in purple and red fleshed potato tubers by analytical methods and near-infrared spectroscopy. J. Sci. Food Agric. DOI 10.1002/jsfa. 7294.

UPOV, 1984. Industrial Property and Plant Breeders Rights (Background Paper: SYMP/1984/4). In Anon., Ed. Industrial Patents and Plant Breeders' Rights - Their Proper Fields and Possibilities for Their Demarcation [Records of a Symposium held on the Occasion of the 18th Session of the Council of UPOV, 17 October 1984]. Geneva, Switzerland. UPOV: 73-95

Vleeshouwers, V.G.A.A; W. van Dooijeweert; L.C.P. Keizer; L. Sijpkes; F. Govers; L. Colon. 1999. A laboratory assay for Phytophthora infestans resistance in various Solanum species reflects the field situation. Eur. J. Plant Pathol., 105: 241-250. 